\title{
Obesitas, Pola Diet, dan Aktifitas Fisik dalam Penanganan Diabetes Melitus pada Masa Pandemi Covid-19
}

\author{
Hasnabila Esti Ardiani, Tria Astika Endah Permatasari*, Sugiatmi \\ Program Studi Gizi, Fakultas Kedokteran dan Kesehatan, Universitas Muhammadiyah Jakarta, Indonesia \\ *Corresponding author: tria.astika@umj.ac.id
}

\begin{abstract}
Background: Diabetes mellitus (DM) can increase the risk of death in Covid-19 patients. Diabetes mellitus is a chronic metabolic disease or disorder characterized by high blood sugar levels accompanied by impaired carbohydrate, lipid, and protein metabolism as a result of insulin function insufficiency. This multi-etiology disease is caused by several main determinants includes obesity, diet patterns, and physical activity. The incidence of DM cases globally continues to increase significantly. The results of Basic Health Research (Riskesdas) show that the prevalence of DM increased from $6.9 \%$ in 2013 to $8.5 \%$ in 2018 according to the blood sugar examinations. The prevalence of DM is not only increasing in the adult age group but also in the adolescent age group. The purpose of writing this article is to scientifically examine the handling of DM from obesity factors, dietary patterns, and physical activity. Results: Patients with diabetes mellitus experience insulin function insufficiency due to disruption of insulin production in the pancreas, so insulin has difficulty converting glucose into energy. Blood glucose levels have a significant relationship with the amount of fat in the body associated with obesity, diet, and energy intake from physical activity. The success of handling DM by controlling various determinants also determined by psychosocial conditions and support from the family. Conclusion: Management of DM can be carried out optimally with a healthy lifestyle, namely by maintaining normal nutritional status and preventing obesity, setting a healthy diet through a balanced diet, and doing physical activity, especially by exercising regularly.
\end{abstract}

Keywords: physical activity, covid-19, diabetes mellitus, obesity, diet pattern

\begin{abstract}
ABSTRAK
Latar belakang: Penyakit diabetes melitus (DM) dapat meningkatkan risiko kematian pada pasien Covid-19. Diabetes melitus merupakan merupakan penyakit atau gangguan metabolisme kronis yang ditandai dengan tingginya kadar gula darah disertai gangguan metabolisme karbohidrat, lipid, dan protein sebagai akibat insufisiensi fungsi insulin. Penyakit dengan multi etiologi ini disebabkan oleh beberapa determinan utama mencakup obesitas, pola diet, dan aktifitas fisik. Insiden kasus diabetes melitus secara global terus meningkat secara signifikan di berbagai negara. Hasil Riset Kesehatan Dasar (Riskesdas) tahun 2018 menunjukkan bahwa prevalensi diabetes melitus menurut hasil pemeriksaan gula darah meningkat dari 6,9\% pada 2013 menjadi 8,5\% di Indonesia. Prevalensi penyakit ini tidak hanya meningkat pada kelompok usia dewasa namun juga pada kelompok usia remaja yaitu usia 15 tahun. Tujuan dari penulisan artikel ini adalah untuk menelaah secara ilmiah penanganan DM dari faktor obesitas, pola diet, dan aktifitas fisik. Hasil: Penderita diabetes melitus mengalami
\end{abstract}


insufisiensi fungsi insulin akibat terjadinya gangguan atau produksi insulin dalam pankreas, sehingga insulin mengalami kesulitan dalam mengubah glukosa menjadi energi. Kadar glukosa dalam darah memiliki hubungan signifikan dengan jumlah lemak dalam tubuh yang terkait dengan obesitas, pola makan, serta pengambilan energi dari aktifitas fisik. Keberhasilan penanganan diabetes melitus dengan mengontrol berbagai determinan juga ditentukan oleh kondisi psikososial serta dukungan dari keluarga. Kesimpulan: Penanganan diabetes melitus dapat dilakukan secara optimal melalui pengaturan pola hidup sehat yaitu dengan mempertahankan status gizi normal dan mencegah obesitas, pengaturan pola makan yang sehat melalui asupan gizi seimbang, serta melakukan aktifitas fisik terutama dengan berolahraga secara rutin.

Kata kunci: aktifitas fisik, covid-19, diabetes melitus, obesitas, pola diet

\section{PENDAHULUAN}

Diabetes melitus (DM) merupakan penyebab kematian ketujuh di dunia dan penyebab utama komplikasi penyakit lainnya seperti serangan jantung, stroke, gagal ginjal, kebutaan, dan amputasi anggota tubuh bagian bawah (1). Diabetes melitus terdiri dari banyak gangguan yang ditandai dengan hiperglikemia. Klasifikasi DM secara umum terdiri dua jenis utama yaitu diabetes tipe 1 dan DM tipe 2 (2). DM tipe 2 lebih banyak terjadi dibandingkan DM tipe 1 (juvenile diabetes atau insulindependent diabetes). Penyakit DM tipe 2 secara umum terjadi pada orang dewasa yang disebabkan oleh pola hidup yang tidak sehat sedangkan DM tipe 1 terjadi karena pankreas menghasilkan sedikit atau bahkan tidak memproduksi insulin $(2,3)$. Penyakit DM tipe 2 merupakan penyakit degeneratif yang menjadi prediktor signifikan morbiditas dan mortalitas yang memiliki hubungan timbal balik dengan penyakit Covid-19. Penderita DM yang terpapar Covid-19 memiliki peningkatan risiko untuk mengalami dibandingkan penderita DM yang tidak terpapar Covid-19, sebaliknya penderita Covid-19 memiliki potensi mengalami kerusakan pankreas akibat aktivitas virus corona (SARS-CoV-2) (4,5). Tingginya kadar gula darah yang berinteraksi dengan faktor lain seperti usia lansia, obesitas, pola makan tidak sehat, rendahnya aktifitas fisik dan adanya penyakit komorbid lainnya dapat memodulasi respons imun dan inflamasi, sehingga membuat pasien DM rentan terhadap paparan Covid-19 (5). Oleh karena itu, penanganan yang tepat dan optimal terhadap faktor risiko tersebut terutama obesitas, pola makan, dan aktifitas fisik untuk meningkatkan sistem kekebalan tubuh pada penderita DM dapat mencegah terjadinya dampak buruk terhadap status kesehatan akibat paparan Covid-19 (6-9).

Penderita diabetes melitus memiliki kadar gula darah yang tinggi disertai adanya gangguan metabolisme karbohidrat, lipid, dan protein sebagai akibat rusaknya fungsi insulin. Kondisi ini disebabkan oleh gangguan atau defisiensi produksi insulin oleh sel-sel beta Langerhans kelenjar pankreas, atau disebabkan rendahnya respons sel-sel tubuh terhadap insulin (10). Berdasarkan kriteria dari World Health Organization (WHO) dan American Diabetes Association (ADA) yang diadopsi oleh Persatuan Endokrinologi Indonesia (Perkeni) mengidentifikasi penderita DM melalui pemeriksaan gula darah. Kriteria diagnosis DM meliputi 4 (empat) hal yaitu: 1) pemeriksaan glukosa plasma puasa 
(puasa selama minimal 8 jam tanpa asupan kalori) yaitu $\geq 126 \mathrm{mg} / \mathrm{dl}, 2$ ) pemeriksaan glukosa plasma sewaktu yaitu $\geq 200 \mathrm{mg} / \mathrm{dl}$, 3) pemeriksaan glukosa plasma $\geq 200 \mathrm{mg} / \mathrm{dl}$ 2 jam setelah Tes Toleransi Glukosa Oral (TTGO) dengan beban glukosa 75 gram, dan 4) pemeriksaan Hemoglobin glikat (HbA1C) dimana jika nilainya lebih dari $6,5 \%$ dapat diidentikkan dengan terjadinya diabetes dengan gejala sering lapar, sering haus, sering buang air kecil dalam jumlah banyak, dan berat badan turun $(1,2,10,11)$.

Prevalensi penyakit DM terus meningkat seiring dengan lonjakan kasus di berbagai negara Covid-19 (5). Insiden kasus diabetes melitus di seluruh dunia meningkat $102,9 \%$ dari 11.303 .084 kasus pada tahun 1990 menjadi 22.935.630 kasus pada tahun 2017 di seluruh dunia (12). Sebelum masa pandemi Covid-19, sekitar 422 juta orang di seluruh dunia menderita diabetes dengan kontribusi terbesar berasal dari negara berpenghasilan rendah dan menengah, dimana sebanyak 1,6 juta kematian di dunia secara langsung dikaitkan dengan diabetes setiap tahun. Jumlah ini diperkirakan meningkat menjadi 570 juta pada tahun 2030 dan menjadi 700 juta pada tahun 2045, dan meningkat secara signifikan selama masa pandemi Covid-19 $(1,3,12)$. Organisasi International Diabetes Federation (IDF) memperkirakan angka prevalensi DM di dunia pada tahun 2019 pada usia 20-70 tahun adalah sebesar 9,3\%, dimana prevalensi DM pada laki-laki sedikit lebih tinggi $(9,65 \%)$ dibandingkan pada perempuan (9\%). Tiga negara dengan prevalensi DM tertinggi di dunia adalah China (116,4\%), India (77,0\%), dan Amerika Serikat $(31,0 \%)$. Sedangkan Indonesia menduduki peringkat ketujuh dengan prevalensi sebesar 10,7\% (13). Hasil Riset Kesehatan Dasar (Riskesdas) tahun 2018 menunjukkan bahwa prevalensi diabetes melitus menurut hasil pemeriksaan gula darah meningkat dari 6,9\% pada 2013 menjadi $8,5 \%$ di Indonesia. Peningkatan prevalensi DM di Indonesia terus meningkat setiap tahun dimana Provinsi DKI Jakarta, Provinsi Kalimantan Timur, dan Provinsi Daerah Istimewa Yogyakarta (DIY) menempati provinsi dengan prevalensi DM tertinggi secara berturut-turut pada penduduk kelompok umur $\geq 15$ tahun maupun penduduk semua umur menurut provinsi $(13,14)$.

Peningkatan prevalensi DM menjadi beban bagi perekonomian negara. Efek spesifik yang ditimbulkan dari DM dalam jangka panjang yaitu terjadinya retinopati, nefropati dan neuropati, serta berisiko tinggi terkena penyakit lain termasuk jantung, penyakit arteri perifer dan serebrovaskular, obesitas, katarak, disfungsi ereksi, dan Nonalcoholic Fatty Liver Diseases (NAFLD). Selain itu penderita DM berisiko lebih tinggi terkena beberapa penyakit menular, termasuk tuberculosis (TB) dan Covid-19 (2,5,12). Pandemi Coronavirus Disease 2019 (COVID-19) di seluruh dunia termasuk di Indonesia menyebabkan dampak infeksi yang lebih parah pada penderita dengan penyakit komorbid termasuk DM. Kondisi ini semakin parah oleh obesitas, pola makan yang tidak sehat, dan kurangnya aktifitas fisik yaitu memiliki pola hidup sedentari (sedentary lifestyle) $(6,7,12,15)$.

Pola hidup sedentari (sedentary lifestyle) yaitu pola hidup dengan aktifitas fisik yang kurang sehingga menyebabkan kelebihan berat badan dan obesitas merupakan faktor penyebab terjadinya yang dapat dimodifikasi, disamping faktor lainnya seperti pola makan yang tidak seimbang, riwayat toleransi glukosa terganggu atau terganggu glukosa darah puasa dan merokok. Selain itu DM dapat dipengaruhi oleh faktor yang tidak dapat dimodifikasi antara 
lain umur, jenis kelamin, riwayat keluarga DM, riwayat persalinan dengan berat badan lebih dari 4000 gram (7,13). Penanganan DM yang optimal terutama pada masa pandemi Covid-19 ditekankan melalui manajemen faktor yang dapat dimodifikasi terutama melakukan pola hidup sehat yaitu mencakup upaya untuk mencapai dan mempertahankan status gizi normal untuk mencegah obesitas, menerapkan pola makan dengan prinsip gizi seimbang, serta melakukan aktifitas fisik dengan berolahraga secara rutin sesuai usia. Kepatuhan penderita DM dalam menerapkan pola hidup sehat dipengaruhi oleh pendidikan dan pengetahuan, serta adanya dukungan dari lingkungan terutama keluarga (16,17). Tujuan dari penulisan tinjauan literatur ini yaitu untuk mengulas secara ilmiah mengenai penanganan diabetes melitus berdasarkan determinannya yaitu obesitas, pola makan, dan aktifitas fisik pada masa pandemi Covid19.

\section{TINJAUAN LITERATUR}

\section{Pengendalian Obesitas dalam Penanganan Diabetes Melitus}

Obesitas salah satu penyebab utama terjadinya DM tipe 2. Penderita DM yang mengalami obesitas memiliki risiko lebih besar untuk terkena penyakit penyerta lainnya termasuk potensi yang tinggi terpapar Covid-19. Selain itu faktor imunitas pasien juga menjadi penentu risiko dari paparan virus tersebut. Kegemukan dan obesitas terjadi ketika akumulasi lemak berlebih. Indikator yang paling mudah dikenali adalah berat badan lebih dimana terjadi distribusi lemak yang memicu ekspresi penyakit penyerta lainnya terutama DM $(18,19)$. World Health Organization (WHO) mengkategorikan Indeks Massa Tubuh (IMT) berdasarkan indeks antropometri yaitu mencapai $>25 \mathrm{~kg} / \mathrm{m}^{2}$ untuk kategori kegemukan, dan obesitas jika IMT > $30 \mathrm{~kg} / \mathrm{m}^{2}(18,20)$. Indeks Massa Tubuh (IMT) yang berlebihan dapat mengalami hambatan dalam pengambilan glukosa ke dalam otot dan sel lemak sehingga hal ini menyebabkan glukosa dalam darah meningkat (21). Penderita DM yang mengalami obesitas biasanya memiliki peradangan kronis tingkat rendah yang menjadi predisposisi terhadap risiko infeksi yang lebih tinggi dan berdampak lebih fatal hingga dapat menyebabkan kematian $(22,23)$. Peradangan sistemik yang diinduksi oleh obesitas menurunkan imunitas bawaan dan adaptif dengan cara yang sama seperti yang dipengaruhi oleh immunosense (24).

Obesitas pada penderita DM menyebabkan gangguan metabolisme dan resistensi insulin (25). Akumulasi lemak dalam tubuh akan menghasilkan asam lemak bebas yang digunakan untuk cadangan energi. Jumlah asam lemak non esterified, gliserol, hormon, sitokin, penanda proinflamasi, dan zat lain yang terlibat dalam pengembangan resistensi insulin meningkat. Kelebihan asam lemak bebas akan mengganggu pengambilan glukosa oleh otot sehingga dapat menyebabkan hiperglikemia. Selain itu insufisiensi insulin dapat menghambat pengambilan glukosa ke dalam otot dan sel lemak sehingga terjadi peningkatan glukosa dalam darah. Jika tidak dilakukan pengendalian terhadap obesitas pada penderita DM yaitu dengan menurunkan IMT hingga mencapai normal $\left(18,5-25,0 \mathrm{~kg} / \mathrm{m}^{2}\right)$ maka peningkatan glukosa dalam darah akan terus terjadi dan menyebabkan dampak yang lebih merugikan $(26,27)$.

Berbagai studi sebelumnya menunjukkan bahwa obesitas secara signifikan dapat memperburuk kesehatan penderita DM $(7,21,28,29)$. Martina dan Adisasmita melaporkan hasil studinya pada 
tahun 2019 yaitu dengan menganalisis data Indonesian Family Life Survey (IFLS)5 melaporkan bahwa individu yang obese memiliki risiko 1,63 kali lebih tinggi terkena DM dibandingkan mereka yang tidak obese. Risiko DM meningkat $13,4 \%$ pada individu yang obesitas dan memiliki aktivitas fisik yang rendah (7). Lam, et al pada tahun 2020 juga menguraikan bahwa obesitas dan diabetes melitus secara bersinergis dapat menyebabkan gangguan metabolisme dalam pancreas yang dapat memodulasi karsinogenesis pankreas (28). Keparahan tersebut semakin meningkat jika penderita DM terpapar infeksi, terutama Covid-19. Santos, et al pada tahun 2021 juga telah menelaah bahwa infeksi virus dapat mengaktifkan respons stres terintegrasi, termasuk aktivasi serin kinase, yang menginduksi fosforilasi serin IRS-1 (Insulin Receptor Substrate 1) dan resistensi insulin (29). Besarnya dampak negatif yang ditimbulkan akibat obesitas terhadap penderita DM, maka perlu adanya perlakuan terhadap pengendalian obesitas. Bramante, Lee, dan Gudzune melaporkan bahwa lebih dari $90 \%$ penderita diabetes mengalami kelebihan berat badan atau obesitas maka diperlukan upaya penanganan melalui berbagai pendekatan mencakup pemberian edukasi dan konseling mengenai perubahan perilaku sedentari menjadi perilaku hidup sehat, manajemen diet, mengikuti program penurunan berat badan, dan melalui manajemen pengobatan $(25,30,31)$.

\section{Pola Diet dalam Penanganan Diabetes Melitus}

Pola diet secara langsung berkaitan dengan status gizi (32,33). Pemenuhan asupan makanan secara seimbang pada penderita DM merupakan faktor utama dalam mencegah terjadinya paparan Covid-19.
Kecukupan gizi pada penderita DM menjadi mutlak terlebih jika penderita DM juga terpapar Covid-19. Manajemen diet pasien DM dengan infeksi Covid-19 menjadi bagian dari prosedur pengobatan yang harus dipenuhi untuk membantu pemulihan kesehatan tersebut $(34,35)$. Kerentanan yang lebih tinggi serta dampak negatif yang ditimbulkan dari paparan Covid-19 bagi penderita DM mengharuskan adanya perubahan perilaku terutama pola makan. Studi yang dilakukan oleh Nowakowski, et al pada tahun 2020 di Polandia pada 124 penderita DM tipe $1(\mathrm{n}=90)$ dan DM tipe 2 $(n=24)$ menunjukkan bahwa lebih dari $60 \%$ responden menyatakan mulai mengonsumsi makanan yang lebih bergizi dan teratur selama pandemi Covid-19 (34). Desnita, et al pada tahun 2020 juga melaporkan bahwa salah satu upaya untuk mencegah komplikasi penyakit yang lebih serius dan meningkatkan imunitas penderita DM pada masa pandemi Covid-19 di Kota Padang, dilakukan edukasi mengenai pentingnya manajemen diet untuk meningkatkan pengetahuan penderita DM mengenai gizi (35).

Pengaturan pola makan pada penderita DM ditujukan dengan mengurangi asupan gula dan lemak akan menurunkan pemasukan glukosa dalam tubuh, sehingga pemakaian energi dalam tubuh akan mengambil cadangan energi yang tersimpan. Jika glukosa yang digunakan diubah menjadi energi, akan menurunkan kadar glukosa dalam darah (36). Sumber makanan dan minuman yang perlu dihindari pada penderita DM adalah makanan atau minuman yang mengandung gula tinggi seperti kental manis, sirup tinggi gula, aneka kue yang menggunakan tinggi gula, serta aneka makanan yang mengandung indeks glikemik yang tinggi dan menaikkan kandungan gula darah (37-39). Penerapan gizi seimbang menjadi solusi yang tepat 
dalam penanganan DM terutama pada masa pandemi Covid-19 dimana jumlah kalori ditentukan oleh usia dan jenis kelamin. Penerapan 'isi piringku' setiap kali konsumsi makan juga menjadi penting pada penderita DM dan menerapkan 4 (empat) pilar gizi seimbang yaitu mengkonsumsi makanan beraneka ragam dan bergizi seimbang dengan membatasi asupan gula sebanyak 4 sendok makan (50 gram) per orang per hari, menerapkan perilaku hidup bersih dan sehat, memantau berat badan secara teratur, dan melakukan aktifitas fisik (40). Studi sebelumnya melaporkan bahwa terdapat bermacam tipe diet yang dapat diterapkan pada penderita DM, salah satunya adalah diet mediterania yang menganjurkan konsumsi minyak zaitun, ikan, sayurmayur, kacang-kacangan, dan buahbuahan. Studi lainnya melaporkan bahwa diet yang dianjurkan adalah diet keto, yaitu diet rendah karbohidrat dan tinggi asam lemak. Hal ini ditujukan dengan konsumsi glukosa yang rendah, maka asam lemak dari keto akan mengambil alih glukosa sebagai sumber tenaga $(30,31,41)$.

Adipositas menjadi prediktor utama adanya komplikasi penyakit lain yang dapat ditimbulkan. Asupan makanan yang tidak seimbang dengan aktifitas fisik dapat meningkatkan risiko paparan penyakit Covid-19 (32,37,42). Manajemen diet yang sehat diperlukan untuk mengatur pola makan sehingga penderita DM memperoleh gizi seimbang, dimana asupan energi yang dikonsumsi sebanding dengan aktifitas fisik yang dilakukan. Kelebihan gizi pada penderita DM dapat menyebabkan obesitas. Risiko terjadinya obesitas pada penderita DM pada masa pandemi covid-19 semakin meningkat karena adanya kebijakan pembatasan aktifitas bagi masyarakat di luar rumah sehingga menyebabkan rendahnya aktifitas fisik. Oleh karena itu perlu pengaturan pola makan untuk mencegah pertambahan berat badan berlebihan yang berdampak terhadap terjadinya obesitas pada penderita DM (25). Oleh karena itu edukasi gizi seimbang terhadap pasien DM sangat penting untuk merubah perilaku makan yang lebih sehat. Edukasi mengenai gizi seimbang secara efektif diberikan sejak fase awal kehidupan (43). Hal ini sangat penting dilakukan karena pembentukan imunitas tubuh dimulai terbentuk terutama pada periode pemberian ASI eksklusif yang diteruskan dengan pemberian makananan pendamping ASI (MP-ASI) yang tepat (4446). Pola asuh gizi yang diperoleh seseorang tersebut akan menentukan status gizi pada masa selanjutnya, dan membentuk perilaku makan yang lebih permanen $(47,48)$. Selain itu dukungan dari lingkungan terutama keluarga juga berpengaruh secara bermakna terhadap kepatuhan diet pada penderita DM (48).

\section{Aktifitas Fisik dan Penanganan Diabetes Melitus}

Aktifitas fisik menyebabkan pengambilan energi dengan merubah glukosa dalam proses metabolism, sehingga kadar glukosa dalam darah menurun. Kegiatan fisik yang dilakukan pasien DM dapat menambah pemakaian glukosa dalam darah untuk diproses menjadi tenaga serta mengurangi tumpukan lemak dalam jaringan adiposa, sehingga dapat mencegah terjadinya obesitas pada penderita DM. Aktifitas fisik yang dilakukan secara menyenangkan dapat meningkatkan imunitas penderita DM. selain itu olahraga yang dilakukan di pagi hari untuk memperoleh paparan sinar matahari dapat mencegah risiko penularan Covid-19 (6,49). Aktifitas fisik rutin terutama dengan melakukan olahraga dengan memperhatikan usia, frekuensi, intensitas, waktu dan jenis olahraganya, 
akan membantu dalam kontrol glukosa dalam darah. Beberapa bentuk olahraga yang direkomendasikan bagi penderita DM antara lain jalan pagi, aerobik, latihan kekuatan, fleksibilitas, dan keseimbangan (50).

Efek perlindungan aktifitas fisik terhadap terjadinya DM terkait dengan peningkatan sensitivitas insulin dan glukosa. pada kontrol glikemik. Studi yang dilakukan oleh Budi, Saraswati dan Setiawan pada penderita DM tipe 2 di wilayah kerja Puskesmas Kedungmundu Kota Semarang pada tahun 2017 menunjukkan bahwa aktifitas fisik berkorelasi dengan aktifitas fisik. Studi tersebut juga menunjukkan bahwa pasien yang melakukan aktifitas fisik yang rendah cenderung tidak dapat mengontrol kadar gula darahnya dibandingkan penderita DM yang melakukan aktifitas fisik sedang dan tinggi (51). Selain faktor status gizi, pola diet dan aktifitas fisik, terdapat faktor lain yang mempengaruhi keberhasilan penderita DM dalam menangani penyakitnya yaitu pendidikan, tingkat pengetahuan dan dukungan sosial dari lingkungan terutama keluarga $(48,52)$. Studi yang dilakukan oleh Isnaeni terhadap 52 orang penderita DM di RSUD Karanganyar menunjukkan bahwa $63,9 \%$ responden dengan pengetahuan yang baik cenderung lebih patuh diet (48). Oleh karena itu, berdasarkan berbagai teori ilmiah dan studi-studi yang telah dilakukan sebelumnya maka penanganan penyakit DM secara optimal pada masa pandemi Covid-19 harus dilakukan melalui pola hidup sehat dengan mengontrol status gizi agar tidak terjadi obesitas, pengaturan diet, dan melakukan aktifitas fisik secara rutin. Kepatuhan terhadap pola hidup sehat ini diharapkan dapat menurunkan risiko paparan Covid-19 pada penderita DM, atau mengurangi dampak kesehatan yang lebih merugikan akibat paparan virus Covid-19 $(6,16)$.

\section{SIMPULAN}

Dari hasil tinjauan literatur maka dapat disimpulkan bahwa penanganan penyakit diabetes melitus pada masa pandemi Covid19 dapat dilakukan melalui penerapan pola hidup sehat yaitu dengan cara: 1) mempertahankan berat badan ideal untuk memperoleh status gizi normal, sehingga dapat dan mencegah obesitas, 2) menerapkan pola makan yang sehat dengan prinsip gizi seimbang untuk memenuhi Angka Kecukupan Gizi (AKG) baik kebutuhan kalori dari zat makro maupun zat gizi mikro mencakup vitamin dan mineral yang sesuai dengan jenis kelamin dan usianya, serta 3) melakukan aktifitas fisik terutama berolahraga secara teratur dengan mempertimbangkan usia penderita DM, frekuensi, intensitas, waktu, dan jenis olahraga yang dilakukan. Selain ketiga faktor utama yang berperan penting dalam keberhasilan penanganan DM, diperlukan dukungan keluarga dan edukasi secara terus menerus mengenai penanganan DM juga untuk meningkatkan sehingga dapat membentuk kesadaran diri untuk melaksanakan hidup sehat yang selanjutnya dapat membentuk perilaku hidup sehat yang lebih permanen.

\section{UCAPAN TERIMA KASIH}

Penulis mengucapkan terima kasih kepada Program Studi Gizi Fakultas Kedokteran dan Kesehatan Universitas Muhammadiyah Jakarta yang telah memfasilitasi penulisan artikel ini.

\section{KONFLIK KEPENTINGAN}

Penulis menyatakan tidak memiliki konflik kepentingan dengan pihak manapun dalam penulisan artikel ini. 


\section{REFERENSI}

1. World Health Organization (WHO). Insulin and associated devices: access for everybody [Internet]. 2020. Available from: https://www.who.int/publications/i/ite $\mathrm{m} /$ insulin-and-associated-devicesaccess-for-everybody-whostakeholder-workshop-21-and-23-25september-2020

2. World Health Organization (WHO). Classification of diabetes mellitus [Internet]. 2019. Available from: https://www.who.int/publications/i/ite $\mathrm{m}$ /classification-of-diabetes-mellitus

3. World Health Organization (WHO). Diabetes [Internet]. Available from: https://www.who.int/healthtopics/diabetes\#tab=tab_1

4. Hussain A, Bhowmik B, do Vale Moreira NC. COVID-19 and diabetes: Knowledge in progress. Diabetes Res Clin Pract [Internet]. 2020 Apr;162(January):108142. Available from:

https://linkinghub.elsevier.com/retriev e/pii/S0168822720303922

5. Lim S, Bae JH, Kwon H-S, Nauck MA. COVID-19 and diabetes mellitus: from pathophysiology to clinical management. Nat Rev Endocrinol [Internet]. 2021 Jan 13;17(1):11-30. Available from: http://www.nature.com/articles/s4157 4-020-00435-4

6. Hjerkind KV, Stenehjem JS, Nilsen TIL. Adiposity, physical activity and risk of diabetes mellitus: prospective data from the population-based Hunt study, Norway. BMJ Open [Internet]. 2017 Jan 16;7(1):e013142. Available from:

https://bmjopen.bmj.com/lookup/doi/1 0.1136/bmjopen-2016-013142
7. Martina, Adisasmita AC. Association between Physical Activity and Obesity with Diabetes Mellitus in Indonesia. Int J Caring Sci. 2019;12(3):1703-9.

8. Abdullah Al-Mountashiri N, ALZhrani AM, Hafez Ibrahim SF, Othman Mirghani H. Dietary habits, physical activity and diabetes perception among patients with type 2 diabetes mellitus in Tabuk City, Saudi Arabia. Electron Physician [Internet]. 2017 Sep 25;9(9):5179-84. Available from:

http://www.ephysician.ir/index.php/br owse-issues/2017/9/797-5179

9. Lim MA, Pranata R. The Danger of Sedentary Lifestyle in Diabetic and Obese People During the COVID-19 Pandemic. Clin Med Insights Endocrinol Diabetes [Internet]. 2020 Jan 19;13(May):117955142096448. Available from: http://journals.sagepub.com/doi/10.11 77/1179551420964487

10. Direktorat Pencegahan dan Pencegahan Penyakit Tidak Menular Kementerian Kesehatan Republik Indonesia. Penyakit Diabetes Melitus [Internet]. 2020. Available from: http://www.p2ptm.kemkes.go.id/infor masi-p2ptm/penyakit-diabetes-melitus

11. American Diabetes Association (ADA). Classification and Diagnosis of Diabetes: Standards of Medical Care in Diabetes-2019. Diabetes Care [Internet]. 2019 Jan 17;42(Supplement 1):S13-28. Available from: http://care.diabetesjournals.org/lookup /doi/10.2337/dc19-S002

12. Liu J, Ren Z-H, Qiang H, Wu J, Shen M, Zhang L, et al. Trends in the incidence of diabetes mellitus: results from the Global Burden of Disease Study 2017 and implications for 
diabetes mellitus prevention. BMC Public Health [Internet]. 2020 Dec 17;20(1):1415. Available from: https://bmcpublichealth.biomedcentral .com/articles/10.1186/s12889-02009502-x

13. Pusat Data dan Informasi Kementerian Kesehatan Republik Indonesia. Diabetes Melitus [Internet]. 2020. Available from: https://pusdatin.kemkes.go.id

14. Kementerian Kesehatan Republik Indonesia. Hasil Riset Kesehatan Dasar Tahun 2018. Jakarta;

15. Ruiz HH, López Diéz R, Arivazahagan L, Ramasamy R, Schmidt AM. Metabolism, Obesity, and Diabetes Mellitus: Recent Studies in Cellular and Animal Models and Human Subjects Highlight Mechanisms and Consequences of Metabolic Dysfunction. Arterioscler Thromb Vasc Biol. 2020;E166-74.

16. Reddy PH. Can Diabetes Be Controlled by Lifestyle Activities? Curr Res diabetes Obes J. 2017;1(4):19.

17. Rohani R, Ardenny A. Analisis Faktor yang Berhubungan dengan Kepatuhan Diet Penderita Diabetes Melitus. J Prot Kesehat. 2019;7(2):61-7.

18. Fruh SM. Obesity: risk factors, complications, and strategies for sustainable long-term weight management. J Am Assoc Nurse Pract [Internet]. 2017 Oct;29(S1):S3-14. Available from: https://journals.lww.com/01741002201709001-00002

19. Rita E, Saputri IN, Widakdo G, Permatasari TAE, Kurniaty I. Riwayat kontak dan status gizi buruk dapat meningkatkan kejadian tuberkulosis pada anak. J Kesehat Masy
Khatulistiwa. 2020;7(1):20-9.

20. World Health Organization (WHO). Obesity and Overweight [Internet]. 2021. Available from: https://www.who.int/news-room/factsheets/detail/obesity-and-overweight

21. Masi G, Oroh W. Hubungan Obesitas dengan Kejadian Diabetes Melitus di Wilayah Kerja Puskesmas Ranomut Kota Manado. e-journal Keperawatan (e-Kp). 2018;6(1):1-6.

22. Zbinden-Foncea $H$, Francaux $M$, Deldicque L, Hawley JA. Does High Cardiorespiratory Fitness Confer Some Protection Against Proinflammatory Responses After Infection by SARSCoV-2? Obesity [Internet]. 2020 Aug 9;28(8):1378-81. Available from: https://onlinelibrary.wiley.com/doi/10. 1002/oby.22849

23. Pranata R, Lim MA, Yonas E, Vania R, Lukito AA, Siswanto BB, et al. Body mass index and outcome in patients with COVID-19: A dose-response meta-analysis. Diabetes Metab [Internet]. $2021 \quad$ Mar;47(2):101178. Available from: https://linkinghub.elsevier.com/retriev e/pii/S1262363620300975

24. Nieman DC. Coronavirus disease2019: A tocsin to our aging, unfit, corpulent, and immunodeficient society. J Sport Heal Sci [Internet]. 2020 Jul;9(4):293-301. Available from:

https://linkinghub.elsevier.com/retriev e/pii/S2095254620300600

25. Bramante CT, Lee CJ, Gudzune KA. Treatment of Obesity in Patients With Diabetes. Diabetes Spectr [Internet]. 2017 Nov 15;30(4):237-43. Available from:

http://spectrum.diabetesjournals.org/lo okup/doi/10.2337/ds17-0030 
26. Algoblan A, Alalfi $M$, Khan $M$. Mechanism linking diabetes mellitus and obesity. Diabetes, Metab Syndr Obes Targets Ther [Internet]. 2014 Dec;7:587. Available from: http://www.dovepress.com/mechanis m-linking-diabetes-mellitus-andobesity-peer-reviewed-article-DMSO

27. Hartono B, Fitriani F. Hubungan Indeks Massa Tubuh dengan Diabetes Melitus Tipe 2 di RSUD Dr. Adjidarmo Rangkasbitung Tahun 2016. J Kedokt Meditek [Internet]. 2019 Jun 24;24(68):14-9. Available from:

http://ejournal.ukrida.ac.id/ojs/index.p hp/Meditek/article/view/1697

28. Quoc Lam B, Shrivastava SK, Shrivastava A, Shankar S, Srivastava RK. The Impact of obesity and diabetes mellitus on pancreatic cancer: Molecular mechanisms and clinical perspectives. J Cell Mol Med [Internet]. 2020 Jul 26;24(14):770616. Available from: https://onlinelibrary.wiley.com/doi/10. 1111/jcmm.15413

29. Santos A, Magro DO, EvangelistaPoderoso R, Saad MJA. Diabetes, obesity, and insulin resistance in COVID-19: molecular interrelationship and therapeutic implications. Diabetol Metab Syndr [Internet]. 2021 Dec 1;13(1):23. Available from: https://dmsjournal.biomedcentral.com/ articles/10.1186/s13098-021-00639-2

30. Komalasari T, Permatasari TAE, Supriyatna N. Pengaruh Edukasi Dengan Metode Peer Group Terhadap Perubahan Pengetahuan, Sikap dan Tekanan Darah Pada Lansia Di UPTD Puskesmas Sukahaji Kabupaten Majalengka. Syntax Lit; J Ilm Indones
[Internet]. 2020 May 20;5(5):184. Available from: http://www.jurnal.syntaxliterate.co.id/i ndex.php/syntax-

literate/article/view/1114

31. Astika T, Permatasari E. Peningkatan Pengetahuan dan Perilaku Gizi Seimbang menggunakan Metode Peer Education. Kes Mas J Fak Kesehat Masy. 2017;11(2):114-20.

32. Vijayakumar P, Narayanasamy A, Vellingiri B. Excessive carbohydrate consumption and body mass index: the risk factors for type 2 diabetes mellitus in patients with Prader-Willi syndrome in Tamil Nadu population. J Basic Appl Zool [Internet]. 2018 Dec 29;79(1):54. Available from: https://basicandappliedzoology.spring eropen.com/articles/10.1186/s41936018-0069-8

33. Astika T, Permatasari E. Balance diet practices related to nutritional status. In: Proceedings of The 2nd International Multidisciplinary Conference [Internet]. Jakarta: Universitas Muhammadiyah Jakarta; 2016. p. 757-63. Available from: https://jurnal.umj.ac.id/index.php/IMC /article/view/1267

34. Grabia M, Markiewicz-Żukowska R, Puścion-Jakubik A, Bielecka J, Nowakowski P, Gromkowska-Kępka $\mathrm{K}$, et al. The Nutritional and Health Effects of the COVID-19 Pandemic on Patients with Diabetes Mellitus. Nutrients [Internet]. $2020 \quad$ Sep 30;12(10):3013. Available from: https://www.ncbi.nlm.nih.gov/pmc/art icles/PMC7600117/pdf/nutrients-1203013.pdf

35. Desnita R, Andika M, Efendi Z, Sugiharto. Pemberdayaan Pasien Dan Keluarga Dalam Manajemen Diet 
Diabetes Melitus Pada Masa Pandemi Covid-19 Di Kota Padang. J Implementasi Pengabdi Masy Kesehat. 2020;2(2):52-7.

36. Yamada S. Paradigm Shifts in Nutrition Therapy for Type 2 Diabetes. Keio J Med [Internet]. 2017;66(3):3343. Available from: https://www.jstage.jst.go.jp/article/kjm /66/3/66_2016-0016-IR/_article

37. Sami W, Ansari T, Butt NS, Rashid M, Hamid A. Effect of Diet Counseling on Type 2 Diabetes Mellitus. Int J Sci Technol Res. 2015;4(8):112-8.

38. Permatasari TAE, Chadirin Y. Sweetened Condensed Consumption of More Than 1 Glass Per Day Has an Impact on Underweight Among Children Under Age Five. In: Proceedings of the 4th International Symposium on Health Research (ISHR 2019) [Internet]. Paris, France: Atlantis Press; 2020. p. 615-9. Available from: https://www.atlantispress.com/article/125935054

39. Ojo O, Ojo O, Adebowale F, Wang X$\mathrm{H}$. The Effect of Dietary Glycaemic Index on Glycaemia in Patients with Type 2 Diabetes: A Systematic Review and Meta-Analysis of Randomized Controlled Trials. Nutrients [Internet]. 2018 Mar 19;10(3):373. Available from: http://www.mdpi.com/20726643/10/3/373

40. Kementerian Kesehatan Republik Indonesia. Panduan Gizi Seimbang Pada Masa Covid 19 [Internet]. 2020. Available from: https://covid19.go.id/edukasi/ibu-dananak/panduan-gizi-seimbang-padamasa-pandemi-covid-19

41. Blagosklonny M V. The mystery of the ketogenic diet: benevolent pseudodiabetes. Cell Cycle [Internet]. 2019
Sep 17;18(18):2157-63. Available from:

https://www.tandfonline.com/doi/full/ 10.1080/15384101.2019.1644765

42. Asyumdah, Yuniastuti A, Kuswardinah A. Analysis of Food Consumption Patterns With the Incidence of Type 2 Diabetes Mellitus in Kulon Progo D.I, Yogyakarta. Public Heal Perspect J. 2020;5(2):928.

43. Permatasari TAE, Rizqiya F, Kusumaningati W, Suryaalamsah II, Hermiwahyoeni Z. The effect of nutrition and reproductive health education of pregnant women in Indonesia using quasi experimental study. BMC Pregnancy Childbirth [Internet]. 2021 Dec 4;21(1):180. Available from: https://bmcpregnancychildbirth.biome dcentral.com/articles/10.1186/s12884021-03676-X

44. Permatasari TAE, Sartika RAD, Achadi EL, Purwono U, Irawati A, Ocviyanti D, et al. Exclusive Breastfeeding Intention among Pregnant Mothers. Kesmas Natl Public Heal J [Internet]. 2018 Feb 28;12(3):134-41. Available from: http://jurnalkesmas.ui.ac.id/kesmas/art icle/view/1446

45. Permatasari TAE, Sudartini NW. Do Health Workers Play a Role in Exclusive Breastfeeding among Working Mothers in Industrial Area? J Nutr Sci Vitaminol (Tokyo) [Internet]. 2020;66(Supplement):S94-8.

Available from: https://www.jstage.jst.go.jp/article/jns v/66/Supplement/66_S94/_article

46. Permatasari TAE, Syafruddin A. Early initiation of breastfeeding related to exclusive breastfeeding and 
breastfeeding duration in rural and urban areas in Subang, West Java, Indonesia. J Heal Res. 2016;30(5):337-45.

47. Permatasari TAE. Pengaruh pola asuh pemberian makan terhadap kejadian stunting pada balita. J Kesehat Masy Andalas [Internet]. 2021 Apr 18;14(2):3. Available from: http://jurnal.fkm.unand.ac.id/index.ph $\mathrm{p} / \mathrm{jkma} /$ article/view/527

48. Isnaeni FN, Risti KN, Mayawati H, Arsy MK. Tingkat pendidikan, pengetahuan gizi dan kepatuhan diet pada pasien diabetes mellitus (DM) rawat jalan di RSUD Karanganyar. MPPKI (Media Publ Promosi Kesehat Indones Indones J Heal Promot [Internet]. 2018 May 25;1(2):40-5. Available from: https://jurnal.unismuhpalu.ac.id/index. php/MPPKI/article/view/116

49. Nurayati L, Adriani M. Hubungan Aktifitas Fisik dengan Kadar Gula Darah Puasa Penderita Diabetes Melitus Tipe 2. Amerta Nutr [Internet]. 2017 Oct 23;1(2):80. Available from: https://e-

journal.unair.ac.id/AMNT/article/view $/ 6229$

50. Fadhila R. Pengaruh latihan fisik terhadap kadar glukosa darah penyandang diabetes melitus tipe 2: literature review. J Keperawatan Abdurrab [Internet]. 2019 Jun 25;3(1):17-24. Available from: http://jurnal.univrab.ac.id/index.php/k eperawatan/article/view/766

51. Rahayu KB, Saraswati LD, Setyawan H. Faktor-faktor yang berhubungan dengan kadar gula darah pada penderita diabetes melitus tipe 2 (studi di wilayah kerja Puskesmas Kedungmundu Kota Semarang. J
Kesehat Masy (Undip); Vol 6, No 2 MARET [Internet]. 2018 May 1;6(2):19-28. Available from: https://ejournal3.undip.ac.id/index.php /jkm/article/view/20782

52. Aditya Ginanjar Wicaksono. Hubungan Antara Rasio Kadar Kolestrol Total Terhadap HDL dengan Insidensi Stroke Iskemik di RSUD Sukoharjo (The Relationship Between the Ratio of Cholesterol Total to HDL with the Incidence of Ischemic Stroke in RSUD Sukoharjo). Universitas Muhammadiyah Surakarta. 2014. 